\title{
GMR
}

\section{Polymorphisms in interleukin-6 and interleukin-10 may be associated with risk of preeclampsia}

\author{
D.M. Fan, Y. Wang, X.L. Liu, A. Zhang and Q. Xu \\ Department of Obstetrics, Qingdao Women and Children's Hospital, Qingdao, \\ China \\ Corresponding author: Q. Xu \\ E-mail: xuqianxn@163.com \\ Genet. Mol. Res. 16 (1): gmr16018588 \\ Received March 1, 2016 \\ Accepted November 18, 2016 \\ Published February 23, 2017 \\ DOI http://dx.doi.org/10.4238/gmr16018588 \\ Copyright (C 2017 The Authors. This is an open-access article distributed under the terms of \\ the Creative Commons Attribution ShareAlike (CC BY-SA) 4.0 License.
}

\begin{abstract}
Preeclampsia is a common condition unique to pregnant women. Previous studies have suggested that several cytokines may contribute to defective placental invasion and endothelial damage in this condition. We investigated the influence of four single nucleotide polymorphisms (SNPs) in the promoters of $I L-6(-572 \mathrm{G} / \mathrm{C},-597 \mathrm{G} / \mathrm{A}$, and $-174 \mathrm{G} / \mathrm{C})$ and $I L-10(-592 \mathrm{~A} / \mathrm{C})$ on susceptibility to preeclampsia in a Chinese population. This study included 142 newly diagnosed preeclampsia patients and 260 controls recruited from Qingdao Women and Children's Hospital between January 2013 and May 2015. Genotyping of $I L-6$ and $I L-10$ SNPs was performed using the polymerase chain reaction-restriction fragment length polymorphism method. Logistic regression analysis was then performed to determine the association between these variants and preeclampsia risk. Our findings indicated that compared to the AAgenotype, the $\mathrm{CC}$ and $\mathrm{AC}+\mathrm{CC}$ genotypes of $I L-10-592 \mathrm{~A} / \mathrm{C}$ correlate with elevated risk of developing preeclampsia, with adjusted odds ratios (and 95\% confidence intervals) of $2.45(1.26-4.72)$ and $1.71(1.09-2.68)$, respectively. However, the IL-6 -572G/C, $-597 \mathrm{G} / \mathrm{A}$, and $-174 \mathrm{G} / \mathrm{C}$ polymorphisms were not found
\end{abstract}

Genetics and Molecular Research 16 (1): gmr16018588 
to play a critical role in susceptibility to this disorder. In conclusion, the $I L-10-592 \mathrm{~A} / \mathrm{C}$ genetic variant was observed to be associated with preeclampsia risk in pregnant women.

Key words: Interleukin-6; Interleukin-10; Polymorphism; Preeclampsia

\section{INTRODUCTION}

Preeclampsia is a common condition unique to pregnant women, and is estimated to occur in approximately 3 to $5 \%$ of all pregnancies (Dekker and Sibai, 1998; Dekker et al., 2011; Sibai, 2012). The clinical manifestations of preeclampsia are high blood pressure and proteinuria after 20 weeks of gestation. This condition is associated with serious complications for both the mother and fetus, including acute renal failure, liver injury, intracranial hemorrhage, pulmonary edema, death, preterm birth, or fetal intrauterine growth restriction (Cnattingius et al., 2004; Saftlas et al., 2005; Stella and Sibai, 2006). The etiology of preeclampsia has been widely studied, but the actual mechanisms responsible are not clear. Many previous investigations have shown that several environmental factors play a key role in the pathogenesis of preeclampsia, such as preexisting hypertension, family history of the disease, lack of vitamin C, and vascular endothelial injury (Dekker et al., 2011). Previous studies have shown that polymorphisms in many genes are associated with preeclampsia risk, notably in those encoding nitric oxide synthase 3 , dopamine receptor D1, DRD4, lymphotoxin- $\alpha$, matrix metalloprotease, transforming growth factor- $\beta 1$ (TGF- $\beta 1$ ), cyclooxygenase 2 , and plateletactivating factor acetylhydrolase (Deepthi et al., 2015; Leonardo et al., 2015; Pissetti et al., 2015; Ren et al., 2015; Su et al., 2015; Wolski et al., 2015; Zeng et al., 2016).

Th2/Th1 cytokine balance correlates with pregnancy outcome. Production of Th1 cytokines is inhibited during normal pregnancy, and their excessive expression is likely to induce preeclampsia (Vargas-Rojas et al., 2016). Th1 cells secrete interleukin-2 (IL-2), interferon- $\gamma($ IFN- $\gamma$ ), and tumor necrosis factor- $\alpha$, whereas Th2 cells produce IL-6, IL-10, IL-4, and TGF- $\beta$ (Kiyomi et al., 2015; Talaat et al., 2015; Yuan et al., 2015). Altered plasma concentrations of many cytokines, including TNF- $\alpha$, IL-1 $\beta$, IL-6, IL-10, and IL-18, have been implicated in defective placental invasion and endothelial damage in preeclampsia (Roland et al., 2010; Sarojini et al., 2013; Wang et al., 2014).

IL-6 is an important mediator of the acute phase response, and trophoblastic proliferation, invasion, and differentiation involve modification of IL-6 levels (Santhanam et al., 1991; Erzen et al., 2007). IL-10 is thought to promote the resistance of trophoblastic cells to Fas-mediated apoptosis (Aschkenazi et al., 2002). A deficiency in placental IL-10 has been reported in pregnant women with preeclampsia in comparison to control subjects, and serum IL-10 level is associated with genetic variations in the $I L-10$ promoter (Makris et al., 2006). Several previous studies have analyzed the association between $I L-10$ gene polymorphisms and development of preeclampsia, but their results conflict (Vural et al., 2010; Xie et al., 2011; Valencia Villalvazo et al., 2012; Liu et al., 2015). Moreover, none has investigated the relationship between $I L-6$ genetic variation and risk of this developing this condition in pregnant Chinese women. Therefore, we carried out a study to assess the effect of four promoter single nucleotide polymorphisms (SNPs) in $I L-6(-572 \mathrm{G} / \mathrm{C},-597 \mathrm{G} / \mathrm{A}$, and $-174 \mathrm{G} / \mathrm{C})$ and $I L-10(-592 \mathrm{~A} / \mathrm{C})$ on preeclampsia susceptibility among expectant Chinese women.

Genetics and Molecular Research 16 (1): gmr16018588 


\section{MATERIAL AND METHODS}

\section{Patients}

One hundred and forty-two preeclampsia patients were enrolled in our study between January 2013 and May 2015. All patients were recruited from the Department of Obstetrics at Qingdao Women and Children's Hospital, and had their diagnoses newly confirmed within 1 week.

Preeclampsia was diagnosed according to the following criteria: blood pressure $\geq 140 / 90 \mathrm{mmHg}$ and $24-\mathrm{h}$ urinary protein $\geq 300 \mathrm{mg}$ after 20 weeks of gestation, in addition to complications comprising at least one of the following: blood pressure $\geq 160 / 110 \mathrm{mmHg}$, 24-h urinary protein $\geq 2000 \mathrm{mg}$, serum transaminase $\geq$ two times the normal level, thrombocyte count $<100 \times 10^{9} / \mathrm{L}$, elevated serum lactate dehydrogenase, serum creatinine $>106 \mu \mathrm{M}$, fetal growth restriction, oligohydramnios, persistent headache, or vision disorder.

Between January 2013 and May 2015, 260 women in at least their 20th week of pregnancy were enrolled in our study as control subjects. These women were recruited during regular prenatal examination at the Department of Obstetrics at Qingdao Women and Children's Hospital. Individuals with a history of chronic hypertension, cardiovascular disease, end-stage liver or renal diseases, or diabetes were excluded from this study.

Baseline demographic and clinical measurements, including age, weeks of gestation when enrollment, body mass index, blood pressure, delivery week, 24-h urinary protein level, and birth weight, were collected from medical records of all participants. All patients and control subjects gave their signed informed consent before enrollment, and the performance of this study was approved by the Ethics Committee of the Qingdao Women and Children's Hospital.

\section{Genotyping methods}

A venous blood sample $(5 \mathrm{~mL})$ was obtained from each subject after enrollment, from which DNA was extracted using a TIANGEN Blood DNA Kit (TIANGEN, Beijing, China). A polymerase chain reaction (PCR)-restriction fragment length polymorphism assay was carried out to genotype the $I L-6-572 \mathrm{G} / \mathrm{C},-597 \mathrm{G} / \mathrm{A}$, and $-174 \mathrm{G} / \mathrm{C}$ and $I L-10-592 \mathrm{~A} / \mathrm{C}$ SNPs. Details of the corresponding primers and PCR products are shown in Table 1. PCRs were conducted on a thermocycler (PerkinElmer, Inc., Waltham, MA, USA), as follows: initial denaturation at $94^{\circ} \mathrm{C}$ for $3 \mathrm{~min} ; 30$ cycles of denaturation at $94^{\circ} \mathrm{C}$ for $30 \mathrm{~s}$, annealing at $56^{\circ} \mathrm{C}$ for $30 \mathrm{~s}$, and extension at $72^{\circ} \mathrm{C}$ for $60 \mathrm{~s}$; then a final extension at $72^{\circ} \mathrm{C}$ for $5 \mathrm{~min}$. The $I L-6-572 \mathrm{G} / \mathrm{C},-597 \mathrm{G} /$ $\mathrm{A}$, and $-174 \mathrm{G} / \mathrm{C}$ and $I L-10-592 \mathrm{~A} / \mathrm{C}$ amplification products were digested by BsrBI, FokI, NlaIII, and RsaI, respectively. The reproducibility of the results was verified by repeating the genotyping process for $5 \%$ of the samples in a blind manner.

\begin{tabular}{|c|c|c|}
\hline Polymorphism & Primers $\left(5^{\prime}-3^{\prime}\right)$ & PCR product (bp) \\
\hline$-572 \mathrm{G} / \mathrm{C}$ & $\begin{array}{l}\text { GAGACGCCTTGAAGTAACTG (forward) } \\
\text { AACCAAAGATGTTCTGAACTGA (reverse) }\end{array}$ & 182 \\
\hline$-597 \mathrm{G} / \mathrm{A}$ & $\begin{array}{l}\text { GAGACGCCTTGAAGTAACTG (forward) } \\
\text { AACCAAAGATGTTCTGAACTGA (reverse) }\end{array}$ & 182 \\
\hline$-174 \mathrm{G} / \mathrm{C}$ & $\begin{array}{l}\text { AGCCTCAATGACGACCTA (forward) } \\
\text { GAGCCTCAGACATCTCCAGT (reverse) }\end{array}$ & 223 \\
\hline$-592 \mathrm{~A} / \mathrm{C}$ & $\begin{array}{l}\text { GGTGAGCACTACCTGACTAGC (forward) } \\
\text { CCTAGGTCACAGTGACGTGG (reverse) }\end{array}$ & 412 \\
\hline
\end{tabular}

Genetics and Molecular Research 16 (1): gmr16018588 
Following amplification, 2\% agarose gel electrophoresis was used to detect PCR products, which were observed under ultraviolet light using a Syngene Gel Imaging System (Syngene, Cambridge, UK).

\section{Statistical analysis}

Comparisons of categorical and continuous variables were carried out using the chisquare test and the Student $t$-test. Conformity of genotype frequencies to Hardy-Weinberg equilibrium was assessed by the chi-square test. Associations between the polymorphisms of interest and risk of preeclampsia were determined by unconditional logistic regression analysis, and odds ratios (ORs) with $95 \%$ confidence intervals (CIs) were calculated regarding these relationships. These calculations were performed using the SPSS 17.0 software package (SPSS Inc., Chicago, IL, USA), and P values $<0.05$ were considered to indicate statistical significance.

\section{RESULTS}

The mean ages of patients and controls were $28.12 \pm 5.86$ and $27.85 \pm 5.56$ years, respectively. In comparison to healthy controls, preeclampsia patients showed higher body mass index values $\left(28.76 \pm 4.53\right.$ vs $\left.27.25 \pm 3.75 \mathrm{~kg} / \mathrm{m}^{2}, t=3.58, \mathrm{P}<0.001\right)$ and systolic $(153.60 \pm 12.52$ vs $110.58 \pm 10.54 \mathrm{mmHg}, t=36.55, \mathrm{P}<0.001)$ and diastolic blood pressure $(100.65 \pm 17.56$ vs $76.75 \pm 14.60 \mathrm{mmHg}, t=14.58, \mathrm{P}<0.001)$, a lower number of weeks at delivery (33.57 $\pm 4.10 v s 39.30 \pm 2.55$ weeks, $t=17.25, \mathrm{P}<0.001)$, and reduced birth weights $(2564.60 \pm 674.40 v s 2853.50 \pm 637.55 \mathrm{~g}, t=4.25, \mathrm{P}<0.00$; Table 2$)$. No significant difference was determined between patients and controls with respect to age $(t=0.46, \mathrm{P}=0.32)$ or number of gestation weeks $(t=0.96, \mathrm{P}=0.17)$.

Table 2. Baseline characteristics of preeclampsia patients and control subjects.

\begin{tabular}{l|c|c|c|c}
\hline Variable & Patients $(\mathrm{N}=142)$ & Controls $(\mathrm{N}=260)$ & $t$-test & P value \\
\hline Age, years & $28.12 \pm 5.86$ & $27.85 \pm 5.56$ & 0.46 & 0.32 \\
\hline Weeks of gestation & $25.64 \pm 4.52$ & $26.10 \pm 4.63$ & 0.96 & 0.17 \\
\hline Body mass index, $\mathrm{kg} / \mathrm{m}^{2}$ & $28.76 \pm 4.53$ & $27.25 \pm 3.75$ & 3.58 & $<0.001$ \\
\hline Systolic blood pressure, $\mathrm{mmHg}$ & $153.60 \pm 12.52$ & $110.58 \pm 10.54$ & 36.55 & $<0.001$ \\
\hline Diastolic blood pressure, $\mathrm{mmHg}$ & $100.65 \pm 17.56$ & $76.75 \pm 14.60$ & 14.58 & $<0.001$ \\
\hline Weeks at delivery & $33.57 \pm 4.10$ & $39.30 \pm 2.55$ & 17.25 & $<0.001$ \\
\hline 24-h urinary protein & $2426.54 \pm 512.44$ & - & & $<0.001$ \\
\hline Newborn birth weight, $\mathrm{g}$ & $2564.60 \pm 674.40$ & $2853.50 \pm 637.55$ & 4.25 & \\
\hline
\end{tabular}

We then analyzed the distributions of $I L-6-572 \mathrm{G} / \mathrm{C},-597 \mathrm{G} / \mathrm{A}$, and $-174 \mathrm{G} / \mathrm{C}$ and $I L-$ $10-592 \mathrm{~A} / \mathrm{C}$ genotypes within the two study groups (Table 3). A chi-square test indicated a significant difference in $I L-10-592 \mathrm{AA}, \mathrm{AC}$, and CC genotype frequencies between the preeclampsia patients and controls (chi-square $=8.81, \mathrm{P}=0.01$ ). However, no significant variation in the frequencies of $I L-6-572 \mathrm{G} / \mathrm{C},-597 \mathrm{G} / \mathrm{A}$, and $-174 \mathrm{G} / \mathrm{C}$ genotypes was observed between the two investigated groups. Moreover, genotype distributions of the $I L-6-572 \mathrm{G} / \mathrm{C}$ (chi-square $=0.80, \mathrm{P}=0.37$ ), $-597 \mathrm{G} / \mathrm{A}$ (chi-square $=0.51, \mathrm{P}=0.48$ ), and $-174 \mathrm{G} / \mathrm{C}$ (chi-square $=0.17, \mathrm{P}=0.68)$ and $I L-10-592 \mathrm{~A} / \mathrm{C}$ (chi-square $=0.28, \mathrm{P}=0.60)$ SNPs in the control group were in agreement with Hardy-Weinberg equilibrium.

Genetics and Molecular Research 16 (1): gmr16018588 
Table 3. $I L-6-572 \mathrm{G} / \mathrm{C},-597 \mathrm{G} / \mathrm{A}$, and $-174 \mathrm{G} / \mathrm{C}$ and $I L-10-592 \mathrm{~A} / \mathrm{C}$ genotype distributions.

\begin{tabular}{|c|c|c|c|c|c|c|c|c|}
\hline SNP & Patients & $\%$ & Controls & $\%$ & Chi-square & $P$ value & Chi-square (HWE) & $\mathrm{P}$ value (HWE) \\
\hline \multicolumn{9}{|c|}{$-572 \mathrm{G} / \mathrm{C}$} \\
\hline GG & 66 & 46.48 & 136 & 52.31 & & & & \\
\hline $\mathrm{GC}$ & 58 & 40.84 & 100 & 38.46 & & & & \\
\hline $\mathrm{CC}$ & 18 & 12.68 & 24 & 9.23 & 1.65 & 0.44 & 0.80 & 0.37 \\
\hline \multicolumn{9}{|c|}{$-597 \mathrm{G} / \mathrm{A}$} \\
\hline GG & 136 & 95.77 & 238 & 91.54 & & & & \\
\hline GA & 6 & 4.23 & 22 & 8.46 & & & & \\
\hline AA & 0 & 0.00 & 0 & 0.00 & 2.54 & 0.111 & 0.51 & 0.48 \\
\hline \multicolumn{9}{|c|}{$-174 \mathrm{G} / \mathrm{C}$} \\
\hline GG & 137 & 96.48 & 247 & 95.00 & & & & \\
\hline $\mathrm{GC}$ & 5 & 3.52 & 13 & 5.00 & & & & \\
\hline $\mathrm{CC}$ & 0 & 0.00 & 0 & 0.00 & 0.47 & 0.49 & 0.17 & 0.68 \\
\hline \multicolumn{9}{|c|}{$-592 \mathrm{~A} / \mathrm{C}$} \\
\hline AA & 47 & 33.10 & 119 & 45.77 & & & & \\
\hline $\mathrm{AC}$ & 66 & 46.48 & 111 & 42.69 & & & & \\
\hline $\mathrm{CC}$ & 29 & 20.42 & 30 & 11.54 & 8.81 & 0.01 & 0.28 & 0.60 \\
\hline
\end{tabular}

$\mathrm{SNP}=$ single nucleotide polymorphism; HWE $=$ Hardy-Weinberg equilibrium.

We subsequently examined the relationship between the polymorphisms under investigation and preeclampsia risk (Table 4). Unconditional logistic regression analysis revealed that $I L-10-592 \mathrm{CC}$ and $\mathrm{AC}+\mathrm{CC}$ genotype carriers exhibited a higher susceptibility to preeclampsia than individuals with the wild-type genotype did, with ORs (and 95\% CIs) of 2.45 (1.26-4.72) and 1.71 (1.09-2.68), respectively. However, we did not establish significant associations between preeclampsia and the $I L-6-572 \mathrm{G} / \mathrm{C},-597 \mathrm{G} / \mathrm{A}$, and $-174 \mathrm{G} / \mathrm{C}$ polymorphisms.

\begin{tabular}{|c|c|c|c|c|c|c|}
\hline SNP & Patients & $\%$ & Controls & $\%$ & OR $(95 \% \mathrm{CI})^{1}$ & P value \\
\hline \multicolumn{7}{|l|}{$-572 \mathrm{G} / \mathrm{C}$} \\
\hline GG & 66 & 46.48 & 136 & 52.31 & 1.0 (Ref.) & \\
\hline $\mathrm{GC}$ & 58 & 40.84 & 100 & 38.46 & $1.18(0.74-1.86)$ & 0.46 \\
\hline $\mathrm{CC}$ & 18 & 12.68 & 24 & 9.23 & $1.52(0.72-3.15)$ & 0.22 \\
\hline $\mathrm{GC}+\mathrm{CC}$ & 76 & 53.52 & 124 & 47.69 & $1.24(0.81-1.91)$ & 0.29 \\
\hline \multicolumn{7}{|l|}{$-597 \mathrm{G} / \mathrm{A}$} \\
\hline GG & 136 & 95.77 & 238 & 91.54 & 1.0 (Ref.) & \\
\hline GA & 6 & 4.23 & 22 & 8.46 & $0.47(0.15-1.25)$ & 0.11 \\
\hline $\mathrm{AA}$ & 0 & 0 & 0 & 0 & - & - \\
\hline $\mathrm{GA}+\mathrm{AA}$ & 6 & 4.29 & 22 & 8.46 & $0.47(0.15-1.25)$ & 0.11 \\
\hline \multicolumn{7}{|l|}{$-174 \mathrm{G} / \mathrm{C}$} \\
\hline GG & 137 & 96.48 & 247 & 95 & 1.0 (Ref.) & \\
\hline $\mathrm{GC}$ & 5 & 3.52 & 13 & 5 & $0.69(0.19-2.13)$ & 0.49 \\
\hline $\mathrm{CC}$ & 0 & 0 & 0 & 0 & - & - \\
\hline $\mathrm{GC}+\mathrm{CC}$ & 5 & 3.52 & 13 & 5 & $0.69(0.19-2.13)$ & 0.49 \\
\hline \multicolumn{7}{|l|}{$-592 \mathrm{~A} / \mathrm{C}$} \\
\hline AA & 47 & 33.10 & 119 & 45.77 & 1.0 (Ref.) & \\
\hline $\mathrm{AC}$ & 66 & 46.48 & 111 & 42.69 & $1.51(0.93-2.44)$ & 0.08 \\
\hline $\mathrm{CC}$ & 29 & 20.42 & 30 & 11.54 & $2.45(1.26-4.72)$ & 0.004 \\
\hline $\mathrm{AC}+\mathrm{CC}$ & 95 & 66.90 & 141 & 54.23 & $1.71(1.09-2.68)$ & 0.01 \\
\hline
\end{tabular}

${ }^{1}$ Adjusted for body mass index, systolic and diastolic blood pressure, weeks at delivery, and newborn birth weight. $\mathrm{SNP}=$ single nucleotide polymorphism; $\mathrm{OR}=$ odds ratio; $\mathrm{CI}=$ confidence interval; Ref. $=$ reference.

\section{DISCUSSION}

Decidual cells producing Th1 and Th2 cytokines maintain a specific immune microenvironment equilibrium during normal pregnancy. If this balance is compromised, 
habitual abortion or complications of pregnancy may result (Kamali-Sarvestani et al., 2005; Choi and Kwak-Kim, 2008). IL-10 is a Th2 cytokine able to promote placental cell growth and differentiation, inhibit lymphocyte proliferation and IFN- $\gamma$ production, and prevent the detrimental effects of killer lymphocytes on trophoblastic cells (Fan et al., 2006). IL-6 is also a Th2 cytokine, and similarly promotes immune tolerance. It can regulate the production of human chorionic gonadotropin from the syncytiotrophoblast, and exert an immunosuppressive effect to maintain pregnancy, although IL-6 expression is elevated for delivery (Aris et al., 2008). In the present study, we observed that the $I L$ $10-592 \mathrm{CC}$ and $\mathrm{AC}+\mathrm{CC}$ genotypes contribute to the development of preeclampsia in the Chinese population.

IL-10 can inhibit production of Th1 cytokines, balance the Th1/Th2 cytokine ratio, upregulate members of the human leukocyte antigen system, promote placental hormone secretion, and maintain pregnancy together with estradiol and progesterone (Wang et al., 2015). Previous in vitro and in vivo experimental studies have indicated that IL-10 expression may influence preeclampsia pathogenesis (Medeiros et al., 2014; Cornelius et al., 2015; Wang et al., 2015).

Previous investigations have tested the association between $I L-10$ gene polymorphisms and preeclampsia development, but with conflicting results (Stonek et al., 2008; Vural et al., 2010; Valencia Villalvazo et al., 2012; Pissetti et al., 2014; Sowmya et al., 2014; Song and Zhong, 2015; Liu et al., 2015). Liu et al. (2015) and Sowmya et al. (2014) reported the IL$10-819 \mathrm{~T} / \mathrm{C}$ genetic variant to be associated with increased preeclampsia risk in pregnant women in China and India. Similarly, in a study of 177 preeclamptic pregnant women and 182 controls, Song and Zhong (2015) found that the $I L-10-592 \mathrm{~A} / \mathrm{C}$ SNP elevated risk of early-onset preeclampsia in a Chinese population. In addition, Pissetti et al. (2014) and Vural et al. (2010) carried out an investigation involving expectant women in Turkey and Brazil, revealing that the $I L-10-1082 \mathrm{~A} / \mathrm{G}$ sequence variant is associated with preeclampsia susceptibility. However, Valencia Villalvazo et al. (2012) and Stonek et al. (2008) failed to detect a correlation between this condition and polymorphisms in $I L-6$ and $I L-10$. In the present study, we identified a significant relationship between the $I L-10-592 \mathrm{~A} / \mathrm{C}$ variant and risk of developing preeclampsia among pregnant women in China. Our findings are thus consistent with those of Song and Zhong (2015). The discrepancies between the abovementioned studies may be attributed to differences in populations, selection of patients and controls, and sample size.

Two limitations to our study should be considered. First, the included patients and controls were recruited from only one hospital in a single Chinese city, and therefore may not be adequately representative of pregnant women in other regions and countries. Second, the sample size in this analysis was not large, potentially restricting its statistical power to distinguish differences between groups. Therefore, further studies incorporating bigger samples of the population are greatly needed to confirm our findings.

In conclusion, we observed that the $I L-10-592 \mathrm{~A} / \mathrm{C}$ polymorphism was associated with the development of preeclampsia. Further large-scale studies should be conducted to gain better insight into the impact of $I L-6$ and $I L-10$ sequence variations on preeclampsia risk.

\section{Conflicts of interest}

The authors declare no conflict of interest.

Genetics and Molecular Research 16 (1): gmr16018588 


\section{ACKNOWLEDGMENTS}

We thank the nurses in the Qingdao Women and Children's Hospital who helped us to collect blood samples from study subjects.

\section{REFERENCES}

Aris A, Lambert F, Bessette P and Moutquin JM (2008). Maternal circulating interferon-gamma and interleukin-6 as biomarkers of Th1/Th2 immune status throughout pregnancy. J. Obstet. Gynaecol. Res. 34: 7-11.

Aschkenazi S, Straszewski S, Verwer KM, Foellmer H, et al. (2002). Differential regulation and function of the Fas/Fas ligand system in human trophoblast cells. Biol. Reprod. 66: 1853-1861. http://dx.doi.org/10.1095/biolreprod66.6.1853

Choi YK and Kwak-Kim J (2008). Cytokine gene polymorphisms in recurrent spontaneous abortions: a comprehensive review. Am. J. Reprod. Immunol. 60: 91-110. http://dx.doi.org/10.1111/j.1600-0897.2008.00602.x

Cnattingius S, Reilly M, Pawitan Y and Lichtenstein P (2004). Maternal and fetal genetic factors account for most of familial aggregation of preeclampsia: a population-based Swedish cohort study. Am. J. Med. Genet. A. 130A: $365-$ 371. http://dx.doi.org/10.1002/ajmg.a.30257

Cornelius DC, Amaral LM, Harmon A, Wallace K, et al. (2015). An increased population of regulatory T cells improves the pathophysiology of placental ischemia in a rat model of preeclampsia. Am. J. Physiol. Regul. Integr. Comp. Physiol. 309: R884-R891. http://dx.doi.org/10.1152/ajpregu.00154.2015

Deepthi G, Chaithri PK, Latha P, Rani VU, et al. (2015). TGFB1 functional gene polymorphisms (C-509T and T869C) in the maternal susceptibility to pre-eclampsia in South Indian women. Scand. J. Immunol. 82: 390-397. http://dx.doi. org $/ 10.1111 / \mathrm{sji} .12342$

Dekker GA and Sibai BM (1998). Etiology and pathogenesis of preeclampsia: current concepts. Am. J. Obstet. Gynecol. 179: 1359-1375. http://dx.doi.org/10.1016/S0002-9378(98)70160-7

Dekker G, Robillard PY and Roberts C (2011). The etiology of preeclampsia: the role of the father. J. Reprod. Immunol. 89: 126-132. http://dx.doi.org/10.1016/j.jri.2010.12.010

Erzen B, Sabovic M, Sebestjen M, Keber I, et al. (2007). Interleukin-6 correlates with endothelial dysfunction in young post-myocardial infarction patients. Cardiology 107: 111-116. http://dx.doi.org/10.1159/000094588

Fan W, Li SW and Liu XR (2006). [Influence of blockade of costimulation on Th1/Th2 cytokines shift in unexplained early recurrent spontaneous]. Sichuan Da Xие Xие Baо Yi Xие Ban 37: 773-775.

Kamali-Sarvestani E, Zolghadri J, Gharesi-Fard B and Sarvari J (2005). Cytokine gene polymorphisms and susceptibility to recurrent pregnancy loss in Iranian women. J. Reprod. Immunol. 65: 171-178. http://dx.doi.org/10.1016/j. jiri.2005.01.008

Kiyomi A, Makita M, Ozeki T, Li N, et al. (2015). Characterization and clinical implication of Th1/Th2/Th17 cytokines produced from three-dimensionally cultured tumor tissues resected from breast cancer patients. Transl. Oncol. 8: 318-326. http://dx.doi.org/10.1016/j.tranon.2015.06.004

Leonardo DP, Albuquerque DM, Lanaro C, Baptista LC, et al. (2015). Association of nitric oxide synthase and matrix metalloprotease single nucleotide polymorphisms with preeclampsia and its complications. PLoS One 10: e0136693. http://dx.doi.org/10.1371/journal.pone.0136693

Liu QY, Gao FY, Liu XR, Li J, et al. (2015). Investigations into the association between polymorphisms in the interleukin-10 gene and risk of early-onset preeclampsia. Genet. Mol. Res. 14: 19323-19328. http://dx.doi.org/10.4238/2015. December.29.42

Makris A, Xu B, Yu B, Thornton C, et al. (2006). Placental deficiency of interleukin-10 (IL-10) in preeclampsia and its relationship to an IL10 promoter polymorphism. Placenta 27: 445-451. http://dx.doi.org/10.1016/j. placenta.2005.05.003

Medeiros LT, Peraçoli JC, Bannwart-Castro CF, Romão M, et al. (2014). Monocytes from pregnant women with preeclampsia are polarized to a M1 phenotype. Am. J. Reprod. Immunol. 72: 5-13. http://dx.doi.org/10.1111/aji.12222

Pissetti CW, Bianco TM, Tanaka SC, Nascentes GA, et al. (2014). [Protective role of the G allele of the polymorphism in the Interleukin 10 gene (-1082G/A) against the development of preeclampsia]. Rev. Bras. Ginecol. Obstet. 36: 456460. http://dx.doi.org/10.1590/SO100-720320140005075

Pissetti CW, Bianco TM, Tanaka SC, Da Silva SR, et al. (2015). Polymorphism in the lymphotoxin-alpha gene, position +252 (rs909253), is not associated with preeclampsia development in Brazilian women. Rev. Bras. Ginecol. Obstet. 37: 516-519. http://dx.doi.org/10.1590/SO100-720320150005454

Ren R, Gao M, Fan P, Liu X, et al. (2015). Association study between -765G $>$ C and -1195G > A functional polymorphisms

Genetics and Molecular Research 16 (1): gmr16018588 
in the cyclooxygenase 2 gene and risk of preeclampsia. Zhonghua Yi Xue Yi Chuan Xue Za Zhi 32: 245-249.

Roland L, Gagné A, Bélanger MC, Boutet M, et al. (2010). Plasma interleukin-18 (IL-18) levels are correlated with antioxidant vitamin coenzyme Q(10) in preeclampsia. Acta Obstet. Gynecol. Scand. 89: 360-366. http://dx.doi. org $/ 10.3109 / 00016340903576020$

Saftlas AF, Beydoun $\mathrm{H}$ and Triche E (2005). Immunogenetic determinants of preeclampsia and related pregnancy disorders: a systematic review. Obstet. Gynecol. 106: 162-172. http://dx.doi.org/10.1097/01.AOG.0000167389.97019.37

Santhanam U, Avila C, Romero R, Viguet H, et al. (1991). Cytokines in normal and abnormal parturition: elevated amniotic fluid interleukin-6 levels in women with premature rupture of membranes associated with intrauterine infection. Cytokine 3: 155-163. http://dx.doi.org/10.1016/1043-4666(91)90037-E

Sarojini A, Sai Ravi Shanker A and Anitha M (2013). Inflammatory markers-serum level of C-reactive protein, tumor necrotic factor-a, and interleukin-6 as predictors of outcome for peripartum cardiomyopathy. J. Obstet. Gynaecol. India 63: 234-239. http://dx.doi.org/10.1007/s13224-013-0428-9

Sibai BM (2012). Etiology and management of postpartum hypertension-preeclampsia. Am. J. Obstet. Gynecol. 206: 470475. http://dx.doi.org/10.1016/j.ajog.2011.09.002

Song L and Zhong M (2015). Association between Interleukin-10 gene polymorphisms and risk of early-onset preeclampsia. Int. J. Clin. Exp. Pathol. 8: 11659-11664.

Sowmya S, Ramaiah A, Sunitha T, Nallari P, et al. (2014). Role of IL-10 -819(t/c) promoter polymorphism in preeclampsia. Inflammation 37: 1022-1027. http://dx.doi.org/10.1007/s10753-014-9824-2

Stella CL and Sibai BM (2006). Preeclampsia: Diagnosis and management of the atypical presentation. J. Matern. Fetal Neonatal Med. 19: 381-386. http://dx.doi.org/10.1080/14767050600678337

Stonek F, Hafner E, Metzenbauer M, Katharina S, et al. (2008). Absence of an association of tumor necrosis factor (TNF)-alpha G308A, interleukin-6 (IL-6) G174C and interleukin-10 (IL-10) G1082A polymorphism in women with preeclampsia. J. Reprod. Immunol. 77: 85-90. http://dx.doi.org/10.1016/j.jri.2007.04.003

Su LH, Liu XH, He GL, Gao Q, et al. (2015). [The Ala379Val polymorphism of platelet-activating factor acetylhydrolase gene in Chinese patients with pre-eclampsia]. Sichuan Da Xue Xue Bao Yi Xue Ban 46: 108-112.

Talaat RM, Mohamed SF, Bassyouni IH and Raouf AA (2015). Th1/Th2/Th17/Treg cytokine imbalance in systemic lupus erythematosus (SLE) patients: Correlation with disease activity. Cytokine 72: 146-153. http://dx.doi.org/10.1016/j. cyto.2014.12.027

Valencia Villalvazo EY, Canto-Cetina T, Romero Arauz JF, Coral-Vázquez RM, et al. (2012). Analysis of polymorphisms in interleukin-10, interleukin-6, and interleukin-1 receptor antagonist in Mexican-Mestizo women with pre-eclampsia. Genet. Test. Mol. Biomarkers 16: 1263-1269. http://dx.doi.org/10.1089/gtmb.2012.0181

Vargas-Rojas MI, Solleiro-Villavicencio H and Soto-Vega E (2016). Th1, Th2, Th17 and Treg levels in umbilical cord blood in preeclampsia. J. Matern. Fetal Neonatal Med. 29: 1642-1645. http://dx.doi.org/10.3109/14767058.2015.1 $\underline{057811}$

Vural P, Degirmencioglu S, Saral NY, Demirkan A, et al. (2010). Tumor necrosis factor alpha, interleukin-6 and interleukin-10 polymorphisms in preeclampsia. J. Obstet. Gynaecol. Res. 36: 64-71. http://dx.doi.org/10.1111/ j.1447-0756.2009.01111.x

Wang A, Liu Q, Zhang J and Zheng R (2015). Berberine alleviates preeclampsia possibly by regulating the expression of interleukin-2/interleukin-10 and Bcl-2/Bax. Int. J. Clin. Exp. Med. 8: 16301-16307.

Wang X, Jiang F, Liang Y, Xu L, et al. (2014). Interleukin-1b-31C/T and -511T/C polymorphisms were associated with preeclampsia in Chinese Han population. PLoS One 9: e106919. http://dx.doi.org/10.1371/journal.pone.0106919

Wolski H, Marek P, Drews K, Barlik M, et al. (2015). DRD1 and DRD4 dopamine receptors in the etiology of preeclampsia. Ginekol. Pol. 86: 672-677. http://dx.doi.org/10.17772/gp/59240

Xie C, Yao MZ, Liu JB and Xiong LK (2011). A meta-analysis of tumor necrosis factor-alpha, interleukin-6, and interleukin-10 in preeclampsia. Cytokine 56: 550-559. http://dx.doi.org/10.1016/j.cyto.2011.09.021

Yuan LF, Li GD, Ren XJ, Nian H, et al. (2015). Rapamycin ameliorates experimental autoimmune uveoretinitis by inhibiting Th1/Th2/Th17 cells and upregulating CD4+CD25+ Foxp3 regulatory T cells. Int. J. Ophthalmol. 8: 659-664.

Zeng F, Zhu S, Wong MC, Yang Z, et al. (2016). Associations between nitric oxide synthase 3 gene polymorphisms and preeclampsia risk: a meta-analysis. Sci. Rep. 6: 23407. http://dx.doi.org/10.1038/srep23407

Genetics and Molecular Research 16 (1): gmr16018588 